\title{
COVID-19 in children in the state of Pernambuco: Spatial analysis of confirmed severe cases and the Human Development Index
}

\author{
Amanda Priscila de Santana Cabral Silva ${ }^{[1],[2],}$ Eliane Rolim de Holanda ${ }^{[3]}$, \\ Paula Daniella de Abreu $^{[4]}$ and Marcelo Victor de Arruda Freitas ${ }^{[1]}$
}

\author{
[1]. Universidade Federal de Pernambuco, Centro Acadêmico Vitória, Núcleo de Saúde Coletiva, Vitória de Santo Antão, PE, Brasil. \\ [2]. Fundação Oswaldo Cruz, Instituto Aggeu Magalhães, Departamento de Saúde Coletiva, Recife, PE, Brasil. \\ [3]. Universidade Federal de Pernambuco, Centro Acadêmico Vitória, Núcleo de Enfermagem, Vitória de Santo Antão, PE, Brasil. \\ [4]. Universidade de São Paulo, Escola de Enfermagem de Ribeirão Preto, \\ Programa de Pós-Graduação de Enfermagem em Saúde Pública, Ribeirão Preto, SP, Brasil.
}

\begin{abstract}
Introduction: Health planning is required for the control and prevention of severe cases of COVID-19 in children. Methods: Spatial analysis of severe COVID-19 cases in children of Pernambuco in the first six months of the pandemic and its autocorrelation with the Human Development Index was conducted. Results: A total of 551 severe cases (39.4 cases/100,000 inhabitants) was initially concentrated in the metropolitan area, with later interiorization. The spatial autocorrelation of cases was identified. The bivariate analysis revealed alert regions in less developed municipalities $(\mathrm{I}=0.341 ; \mathrm{p}=0.001)$. Conclusions: Considering the local particularities can assist in directing the priorities for decision making.
\end{abstract}

Keywords: Pandemic. Coronavirus infections. Child health. Spatial analysis. Surveillance. Public health.

Coronavirus disease 2019 (COVID-19), a disease caused by the severe acute respiratory syndrome coronavirus 2 (SARS-CoV-2), was first recorded in December 2019 in the city of Wuhan, Province of Hubei, China. It was declared a public health emergency of international interest in January 2020 and a pandemic in March of the same year ${ }^{1}$.

Initially, COVID-19 was described as a disease that occurred predominantly in adults and was associated with pneumonia of unknown etiology ${ }^{2}$. The pandemic spread as a result of the high rates of contamination. Pediatric cases appeared less frequently, with a lower frequency of hospitalizations, complications, and fatal outcomes, compared to adults and the elderly ${ }^{3}$. The most severe cases were associated with profiles of children with pre-existing comorbidities ${ }^{3}$.

\footnotetext{
Corresponding author: Amanda Priscila de Santana Cabral Silva. e-mail: amanda.cabral@ufpe.br

(D) https://orcid.org/0000-0003-2337-9925

Received 31 October 2020

Accepted 12 February 2021
}

Despite the collective efforts to contain the pandemic, social inequalities in Brazil are fertile ground for spreading COVID-19. Social isolation is difficult. There is restricted access to basic supplies for hygiene and protection and also limited access to health services. The disparities between the number of beds and respirators per capita in the public and private sectors, and between capitals and hinterland cities, generate distortions that disrupt the efficient distribution of resources and contribute to mortality ${ }^{4}$.

Severe COVID-19 cases in children represent the most detrimental manifestations of the disease in this age group, that places greater demands om the health system. This study aimed to analyze the spatial distribution of severe COVID-19 cases in children and its correlation with the Municipal Human Development Index in the state of Pernambuco.

This ecological study was performed in Pernambuco. The state is divided into 185 municipalities distributed over 12 health regions that are grouped into four macro-health regions (Metropolitan, Agreste, Sertão, and Vale do São Francisco and Araripe) (Figure 1). In 2019, the population was estimated to be $9,557,071$ inhabitants, of which $15.0 \%(n=1,397,623)$ were under 10 years old ${ }^{5}$. 


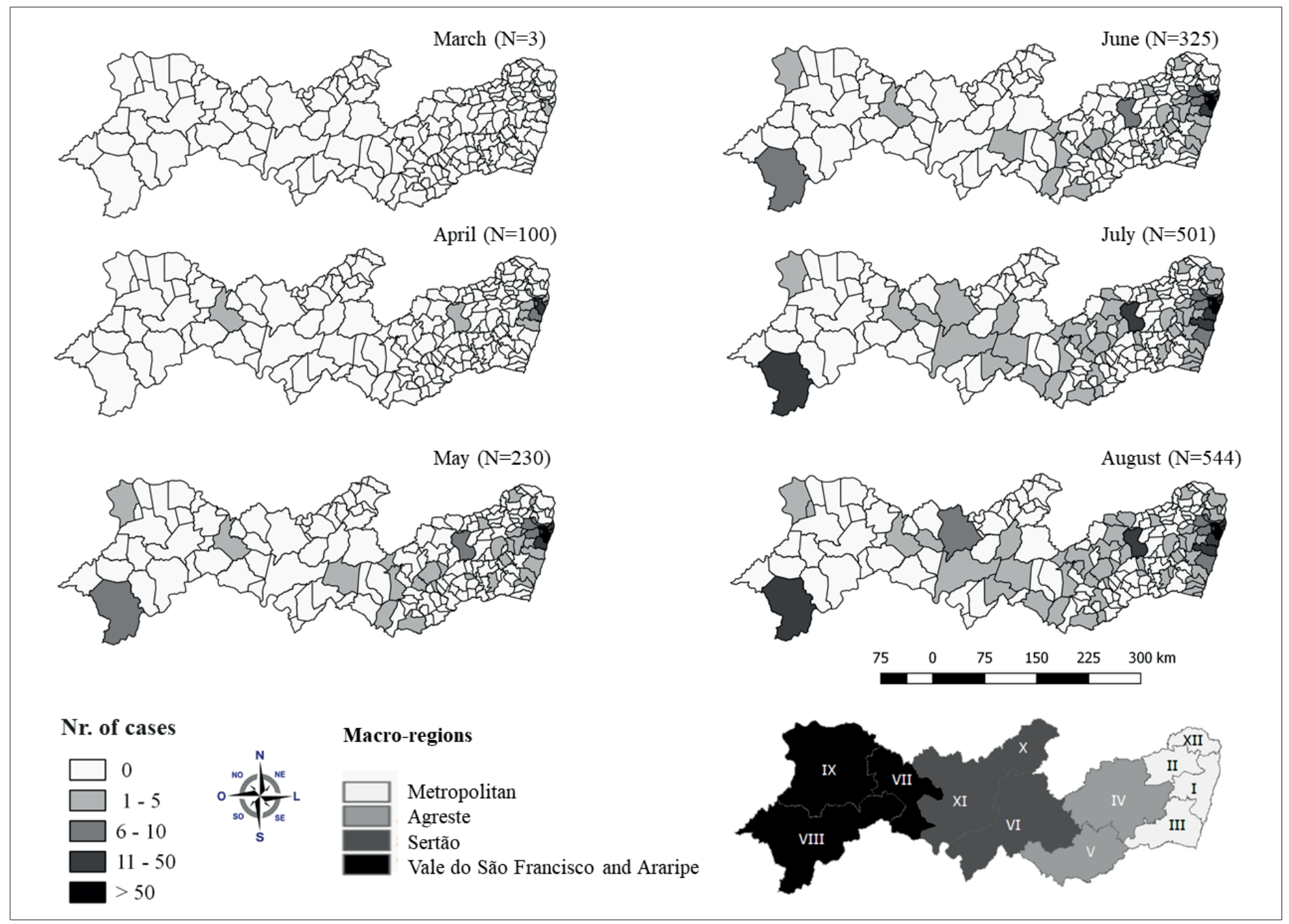

FIGURE 1: Monthly evolution of the spatial distribution of severe cases of COVID-19 in children under 10 years old by residential municipality. Pernambuco, March to August 2020*. Source: Own elaboration * Epidemiological weeks 10 to 35 / 2020.

The study population included individuals under 10 years of age with confirmed severe COVID-19, notified between March 1 and August 29, 2020, which corresponded to epidemiological weeks (Epi week) 10 to 35 of this year. For notification purposes, a case was considered "severe" if the individual was hospitalized for the severe acute respiratory syndrome (SARS), defined as a flu-like syndrome, presenting with dyspnea or persistent pressure in the chest, or $\mathrm{O}_{2}$ saturation below $95 \%$ in room air, or signs of respiratory discomfort.

The rates of detection of severe COVID-19 in children were calculated for each municipality. Local empirical Bayes smoothing was applied to smooth the estimates of coefficients calculated for the small (or underreported) geographical areas, thereby eliminating random fluctuations not associated with the actual risk ${ }^{6}$.

From the smoothed rates, the existence of univariate and bivariate spatial autocorrelation was investigated using the Global Moran's Index. This index provides a single value ranging from -1 to 1 , with 0 being the absence of spatial correlation, a positive value indicating direct correlation, and a negative value indicating inverse correlation. The location of clusters among the classifications in the univariate analysis was detected through local Moran's analysis as follows:

\section{Not significant;}

- High-High (positive values, positive means) and Low-Low (negative values, negative means): indicate a positive spatial association, municipalities where neighbors have similar values;

- High-Low (positive values, negative means) and Low-High (negative values, positive means): indicate a negative spatial association, municipalities where neighbors have different values.

In the bivariate analysis, the smoothed detection rate of severe COVID-19 in children was considered as a dependent variable. The independent variable was the Municipal Human Development Index obtained by the geometric mean of indices of income, education, and longevity dimensions ${ }^{7}$. These are basic and universal dimensions of 
life, which influence the choices and opportunities of individuals ${ }^{8}$. In this correlation analysis, the clusters were classified as described by Maciel et al. (2020)

\section{Not significant;}

- High-High: regions formed by municipalities with high frequencies of the dependent variable and high frequencies of the independent variable;

- Low-Low: regions formed by municipalities with low frequencies of the dependent variable and low frequencies of the independent variable;

- High-Low: regions formed by municipalities with high frequencies of the dependent variable and low frequencies of the independent variable;

- Low-High: regions formed by municipalities with low frequencies of the dependent variable and high frequencies of the independent variable.

Clusters that fit in the High-High quadrant of the Moran Map were defined as critical areas and those in the High-Low quadrant were defined as alert areas.

Additionally, the Kappa coefficient was used to categorize the degree of univariate and bivariate spatial autocorrelation generated by the Global Moran's Index of detection rates of severe COVID-19 cases in children. Values were interpreted as insignificant $(<0.0)$, reasonable $(0.0-0.2)$, weak $(0.21-0.4)$, moderate $(0.41-0.6)$, strong (0.61-0.8), and almost perfect (0.81-1.0).

Spatial analyses were performed using electronic spreadsheets and GeoDA Version 1.14.0 and the QGis 2.18.9 software. The results were represented in the cartographic base of Pernambuco provided by the Brazilian Institute of Geography and Statistics $(\mathrm{IBGE})^{10}$.

Data from cases (obtained on September 4, 2020) are made available by the State Health Department on the "COVID data" (Covid em dados) platform managed by the Pernambuco State Planning Department ${ }^{11}$. The official population estimate for each municipality was obtained from the Brazilian Institute of Geography and Statistics. 5 The Human Development Index was captured in the Human Development Atlas in Brazil7. In this study, we used a secondary database, publicly available, with no possibility of identifying individuals. Therefore, approval by an ethics committee was deemed unnecessary.

In Pernambuco, between Epi weeks 10 and 35 of 2020, 551 severe COVID-19 cases in children were confirmed, representing 39.4 cases/100 thousand inhabitants. More than half of the cases $(n=288)$ were concentrated specifically between Epi week 23 and Epi week 31, which corresponded to the months of June and July 2020, respectively.

Since the record of residential municipality was available in 544 out of the total number of cases, it was possible to perform the spatial analysis. The monthly evolution of the distribution of severe cases in the state showed the initial concentration of cases in municipalities in the metropolitan region of Recife, with subsequent interiorization, especially from May 2020 (Figure 1). In August 2020, 101 municipalities confirmed at least one severe case of COVID-19 in children under the age of 10 years (Figure 1).

Twenty municipalities concentrated mostly in the metropolitan macro-region had a higher detection rate than the state average, above 40.0 cases $/ 100$ thousand inhabitants (Figure 2). Considering the number of cases per 100 thousand inhabitants, the municipalities of Recife (87.6), Camaragibe (69.5), Olinda (68.9), and São Lourenço da Mata (62.8) stood out.

Univariate analysis identified the presence of a positive and strong spatial autocorrelation between the municipal detection rates $(\mathrm{I}=0.73 ; \mathrm{p}=0.001)$. The local Moran analysis revealed a critical region (High-High) formed by municipalities belonging to the metropolitan and agreste macro-regions (Figure 2). In the univariate analysis, in addition to the High-High cluster, there was also a Low-Low pattern distributed in the four macro-regions of the state (Figure 2).

In the Moran Global bivariate analysis between the detection rates of severe cases of COVID-19 in children and the Municipal Human Development Index, a significant positive correlation was found $(\mathrm{I}=0.341 ; \mathrm{p}=0.001)$. When inserting the Municipal Human Development Index as the independent variable, the High-High cluster remained. In particular, in the areas classified as Low-Low in the previous analysis, alert regions were revealed (Figure 2). In this scenario, we highlighted the significant municipalities for the High-Low spatial pattern located in the following macro-regions: Metropolitan (Bom Jardim, Lagoa do Carro, Limoeiro, Orobó and Vicência), Sertão (Afogados da Ingazeira, Ingazeira, Iguaraci, São José do Egito, Tabira, and Tuparetama), and Vale do São Francisco and Araripe (Cabrobó, Moreilandia, Orocó, Parnamirim, and Terra Nova).

Regarding human development, the presence of moderate positive spatial autocorrelation was identified in the distribution of the MHDI in Pernambuco ( $\mathrm{I}=0.46 ; \mathrm{p}=0.001)$, as detailed in Table 1 .

In this study, within the first six months of the pandemic in Pernambuco, the spatial autocorrelation of the occurrence of severe cases of COVID-19 in the pediatric population and the statistically significant cluster with a High-High pattern was located between the Metropolitan and Agreste Macro-regions. The bivariate analysis revealed alert regions (High-Low pattern), which suggested that the living conditions influenced the active spread of the virus among children in the state. Moreover, the effects of the pandemic on this age group may be even more prominent in the less developed areas.

This scenario reinforced that the pandemic course involved not only the transmission and susceptibility characteristics of COVID-19 but also different severities and impairments resulting from social inequality, precarious living, work, income, housing and sanitation conditions, low educational level, and difficulty in accessing water and health services, especially for families residing in urban agglomerations or rural areas far from health facilities and with limited transport infrastructures. These intense social vulnerabilities result in health disparities, as shown in the maps. 


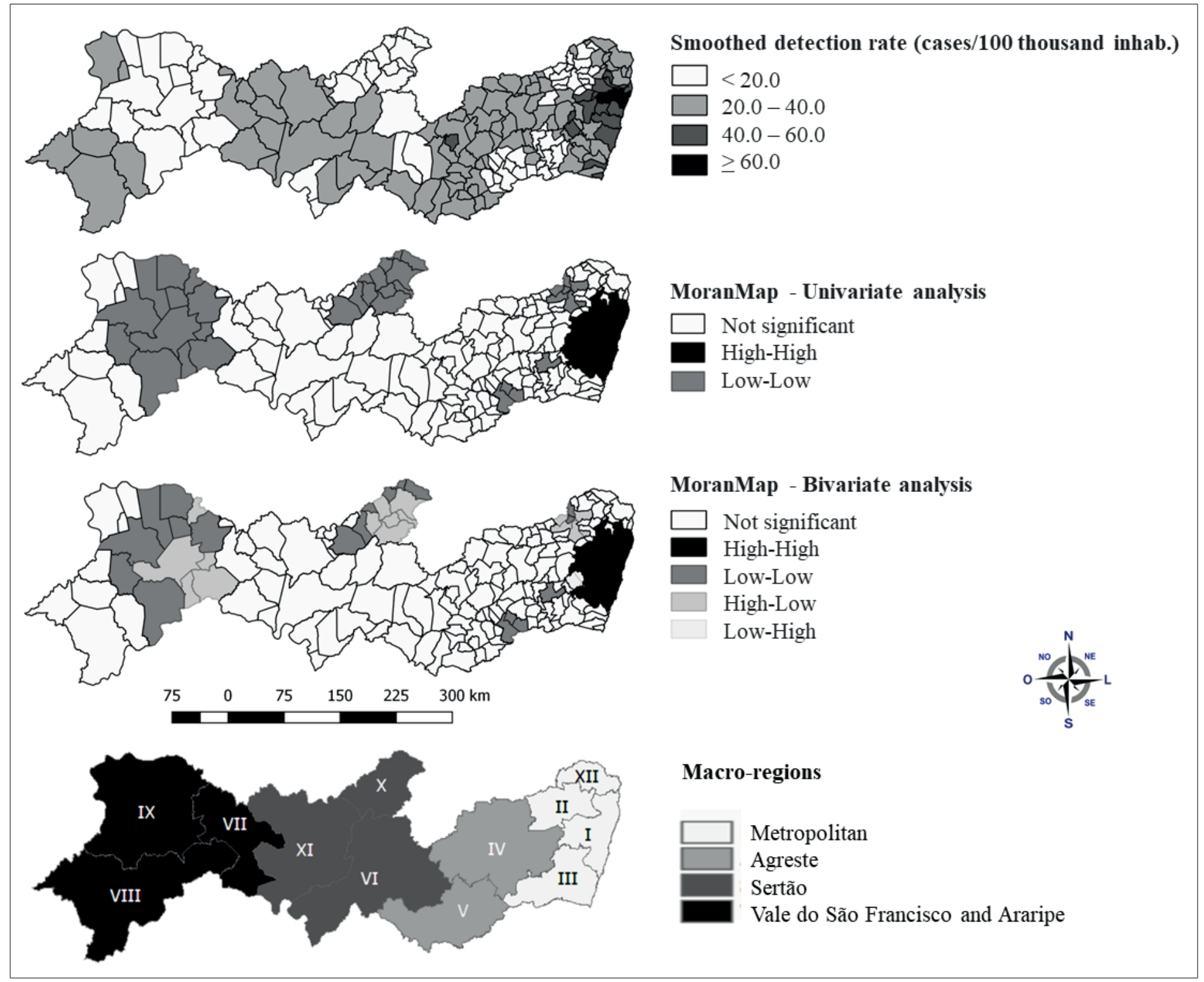

FIGURE 2: Smoothed detection rate of severe cases of COVID-19 in children under 10 years old and distribution by univariate and bivariate analyzes. Pernambuco, March to August 2020. Source: Own elaboration. *Epidemiological weeks 10 to 35 / 2020.

TABLE 1: Distribution of the Municipal Human Development Index (MHDI), Moran Index and p-value. Pernambuco, Brazil 2020.

\begin{tabular}{lccc}
\hline Municipalities & MHDI & Moran Index & p-value \\
\hline Água Preta & 0.553 & 0.097 & 0.398 \\
Águas Belas & 0.526 & 1.918 & 0.000 \\
Abreu e Lima & 0.679 & 2.094 & 0.007 \\
Afogados da Ingazeira & 0.657 & -0.074 & 0.474 \\
Afrânio & 0.588 & -0.167 & 0.065 \\
Agrestina & 0.592 & -0.011 & 0.350 \\
Alagoinha & 0.599 & -0.010 & 0.440 \\
Aliança & 0.604 & 0.068 & 0.187 \\
Altinho & 0.598 & 0.003 & 0.423 \\
Amaraji & 0.580 & -0.010 & 0.431 \\
Angelim & 0.572 & 0.395 & 0.032 \\
Araçoiaba & 0.592 & -0.081 & 0.016 \\
Araripina & 0.602 & -0.076 & 0.184 \\
Arcoverde & 0.667 & -0.557 & 0.236 \\
\hline
\end{tabular}

Continue... 


\begin{tabular}{|c|c|c|c|}
\hline Municipalities & MHDI & Moran Index & $\mathrm{p}$-value \\
\hline Barra de Guabiraba & 0.577 & 0.073 & 0.372 \\
\hline Barreiros & 0.586 & 0.047 & 0.370 \\
\hline Belém de Maria & 0.578 & 0.211 & 0.100 \\
\hline Belém de São Francisco & 0.642 & 0.450 & 0.190 \\
\hline Belo Jardim & 0.629 & -0.416 & 0.048 \\
\hline Betânia & 0.559 & -0.113 & 0.370 \\
\hline Bezerros & 0.606 & -0.006 & 0.455 \\
\hline Bodocó & 0.565 & 0.247 & 0.213 \\
\hline Bom Conselho & 0.563 & 0.852 & 0.002 \\
\hline Bom Jardim & 0.602 & 0.009 & 0.421 \\
\hline Bonito & 0.561 & 0.257 & 0.142 \\
\hline Brejão & 0.547 & 0.491 & 0.186 \\
\hline Brejinho & 0.574 & -0.118 & 0.288 \\
\hline Brejo da Madre de Deus & 0.562 & -0.239 & 0.203 \\
\hline Buíque & 0.527 & 0.935 & 0.047 \\
\hline Buenos Aires & 0.593 & -0.051 & 0.009 \\
\hline Cabo de Santo Agostinho & 0.686 & 2.507 & 0.004 \\
\hline Cabrobó & 0.623 & 0.386 & 0.086 \\
\hline Cachoeirinha & 0.579 & 0.012 & 0.449 \\
\hline Caetés & 0.522 & 0.477 & 0.245 \\
\hline Calçados & 0.566 & 0.290 & 0.189 \\
\hline Calumbi & 0.571 & -0.193 & 0.189 \\
\hline Camaragibe & 0.692 & 4.885 & 0.000 \\
\hline Camocim de São Félix & 0.588 & 0.080 & 0.130 \\
\hline Camutanga & 0.606 & 0.051 & 0.332 \\
\hline Canhotinho & 0.541 & 0.856 & 0.017 \\
\hline Capoeiras & 0.549 & 0.151 & 0.336 \\
\hline Carnaíba & 0.583 & 0.004 & 0.506 \\
\hline Carnaubeira da Penha & 0.573 & -0.383 & 0.046 \\
\hline Carpina & 0.680 & 1.217 & 0.050 \\
\hline Caruaru & 0.677 & -0.064 & 0.476 \\
\hline Casinhas & 0.567 & -0.100 & 0.372 \\
\hline Catende & 0.609 & -0.185 & 0.031 \\
\hline Cedro & 0.615 & 0.354 & 0.137 \\
\hline Chã de Alegria & 0.604 & 0.166 & 0.055 \\
\hline Chã Grande & 0.599 & 0.005 & 0.449 \\
\hline Condado & 0.602 & 0.067 & 0.172 \\
\hline Correntes & 0.536 & 0.457 & 0.256 \\
\hline Cortês & 0.568 & 0.139 & 0.275 \\
\hline Cumaru & 0.572 & 0.088 & 0.342 \\
\hline Cupira & 0.592 & 0.038 & 0.087 \\
\hline Custódia & 0.594 & 0.007 & 0.247 \\
\hline Dormentes & 0.589 & 0.007 & 0.474 \\
\hline Escada & 0.632 & 0.455 & 0.073 \\
\hline Exu & 0.576 & 0.080 & 0.383 \\
\hline Feira Nova & 0.600 & 0.044 & 0.178 \\
\hline Ferreiros & 0.622 & 0.072 & 0.423 \\
\hline Flores & 0.556 & 0.055 & 0.462 \\
\hline Floresta & 0.626 & -0.162 & 0.243 \\
\hline Frei Miguelinho & 0.576 & -0.067 & 0.342 \\
\hline Gameleira & 0.602 & -0.016 & 0.433 \\
\hline Garanhuns & 0.664 & -1.698 & 0.000 \\
\hline Glória do Goitá & 0.604 & 0.066 & 0.157 \\
\hline Goiana & 0.651 & 0.645 & 0.085 \\
\hline Granito & 0.595 & 0.001 & 0.349 \\
\hline Gravatá & 0.634 & -0.134 & 0.306 \\
\hline lati & 0.528 & 1.355 & 0.025 \\
\hline Ibimirim & 0.552 & 0.884 & 0.004 \\
\hline Ibirajuba & 0.580 & 0.202 & 0.057 \\
\hline
\end{tabular}

Continue... 
Silva APSC et al. - COVID-19 in children: Spatial analysis of severe cases and the Human Development Index

\begin{tabular}{|c|c|c|c|}
\hline Municipalities & MHDI & Moran Index & $p$-value \\
\hline Igarassu & 0.665 & 1.567 & 0.002 \\
\hline Iguaraci & 0.598 & 0.025 & 0.140 \\
\hline Ilha de Itamaracá & 0.653 & 1.530 & 0.024 \\
\hline Inajá & 0.523 & 1.254 & 0.035 \\
\hline Ingazeira & 0.608 & 0.142 & 0.174 \\
\hline Ipojuca & 0.619 & 0.499 & 0.059 \\
\hline Ipubi & 0.550 & 0.257 & 0.319 \\
\hline Itaíba & 0.510 & 3.025 & 0.000 \\
\hline Itacuruba & 0.595 & -0.002 & 0.217 \\
\hline Itambé & 0.575 & -0.214 & 0.129 \\
\hline Itapetim & 0.592 & -0.014 & 0.362 \\
\hline Itapissuma & 0.633 & 1.123 & 0.018 \\
\hline Itaquitinga & 0.586 & -0.187 & 0.020 \\
\hline Jaboatão dos Guararapes & 0.717 & 5.658 & 0.000 \\
\hline Jaqueira & 0.575 & 0.385 & 0.037 \\
\hline Jataúba & 0.530 & -0.006 & 0.499 \\
\hline Jatobá & 0.645 & 0.068 & 0.402 \\
\hline Joaquim Nabuco & 0.554 & 0.281 & 0.231 \\
\hline João Alfredo & 0.576 & -0.124 & 0.265 \\
\hline Jucati & 0.550 & 0.110 & 0.418 \\
\hline Jupi & 0.575 & 0.179 & 0.133 \\
\hline Jurema & 0.509 & 1.455 & 0.041 \\
\hline Lagoa de Itaenga & 0.602 & 0.123 & 0.029 \\
\hline Lagoa do Carro & 0.609 & 0.275 & 0.039 \\
\hline Lagoa do Ouro & 0.525 & 0.604 & 0.206 \\
\hline Lagoa dos Gatos & 0.551 & 0.424 & 0.137 \\
\hline Lagoa Grande & 0.597 & 0.010 & 0.307 \\
\hline Lajedo & 0.611 & -0.176 & 0.118 \\
\hline Limoeiro & 0.663 & 0.135 & 0.376 \\
\hline Macaparana & 0.609 & -0.030 & 0.456 \\
\hline Machados & 0.578 & 0.031 & 0.455 \\
\hline Manari & 0.487 & 3.518 & 0.002 \\
\hline Maraial & 0.534 & 0.524 & 0.180 \\
\hline Mirandiba & 0.591 & -0.059 & 0.069 \\
\hline Moreilândia & 0.600 & -0.015 & 0.457 \\
\hline Moreno & 0.652 & 2.176 & 0.001 \\
\hline Nazaré da Mata & 0.662 & 0.504 & 0.159 \\
\hline Olinda & 0.735 & 10.657 & 0.000 \\
\hline Orobó & 0.610 & -0.153 & 0.161 \\
\hline Orocó & 0.610 & 0.063 & 0.323 \\
\hline Ouricuri & 0.572 & 0.280 & 0.065 \\
\hline Palmares & 0.622 & -0.452 & 0.020 \\
\hline Palmeirina & 0.549 & 0.418 & 0.155 \\
\hline Panelas & 0.569 & 0.463 & 0.011 \\
\hline Paranatama & 0.537 & 0.487 & 0.214 \\
\hline Parnamirim & 0.599 & -0.012 & 0.350 \\
\hline Passira & 0.592 & -0.015 & 0.236 \\
\hline Paudalho & 0.639 & 1.045 & 0.001 \\
\hline Paulista & 0.732 & 6.770 & 0.000 \\
\hline Pedra & 0.567 & 0.391 & 0.015 \\
\hline Pesqueira & 0.610 & -0.068 & 0.229 \\
\hline Petrolândia & 0.623 & 0.263 & 0.214 \\
\hline Petrolina & 0.697 & -0.192 & 0.479 \\
\hline Poção & 0.528 & 0.181 & 0.437 \\
\hline Pombos & 0.598 & 0.018 & 0.250 \\
\hline Primavera & 0.580 & -0.098 & 0.201 \\
\hline Quipapá & 0.552 & 1.218 & 0.001 \\
\hline Quixaba & 0.577 & 0.228 & 0.209 \\
\hline
\end{tabular}

Continue... 


\begin{tabular}{|c|c|c|c|}
\hline Municipalities & MHDI & Moran Index & $\mathrm{p}$-value \\
\hline Recife & 0.772 & 9.507 & 0.000 \\
\hline Riacho das Almas & 0.570 & -0.221 & 0.177 \\
\hline Ribeirão & 0.602 & -0.029 & 0.276 \\
\hline Rio Formoso & 0.613 & -0.050 & 0.392 \\
\hline Sairé & 0.585 & 0.010 & 0.498 \\
\hline Salgadinho & 0.534 & -0.369 & 0.244 \\
\hline Salgueiro & 0.669 & 0.365 & 0.246 \\
\hline Saloá & 0.559 & 0.595 & 0.019 \\
\hline Sanharó & 0.603 & 0.059 & 0.270 \\
\hline Santa Cruz & 0.549 & 0.342 & 0.220 \\
\hline Santa Cruz da Baixa Verde & 0.612 & 0.317 & 0.080 \\
\hline Santa Cruz do Capibaribe & 0.648 & -0.450 & 0.242 \\
\hline Santa Filomena & 0.533 & 0.762 & 0.144 \\
\hline Santa Maria da Boa Vista & 0.590 & 0.016 & 0.437 \\
\hline Santa Maria do Cambucá & 0.548 & 0.142 & 0.431 \\
\hline Santa Terezinha & 0.593 & -0.010 & 0.318 \\
\hline São Benedito do Sul & 0.530 & 1.237 & 0.018 \\
\hline São Bento do Una & 0.593 & 0.012 & 0.236 \\
\hline São Caetano & 0.591 & 0.002 & 0.486 \\
\hline São Joaquim do Monte & 0.537 & 0.256 & 0.323 \\
\hline São João & 0.570 & 0.162 & 0.268 \\
\hline São José da Coroa Grande & 0.608 & -0.057 & 0.416 \\
\hline São José do Belmonte & 0.610 & 0.171 & 0.162 \\
\hline São José do Egito & 0.635 & 0.112 & 0.343 \\
\hline São Lourenço da Mata & 0.653 & 2.206 & 0.000 \\
\hline São Vicente Ferrer & 0.549 & -0.126 & 0.345 \\
\hline Serra Talhada & 0.661 & -0.112 & 0.416 \\
\hline Serrita & 0.595 & -0.002 & 0.176 \\
\hline Sertânia & 0.613 & -0.165 & 0.156 \\
\hline Sirinhaém & 0.597 & 0.014 & 0.191 \\
\hline Solidão & 0.585 & -0.098 & 0.217 \\
\hline Surubim & 0.635 & -0.488 & 0.031 \\
\hline Tabira & 0.605 & 0.083 & 0.172 \\
\hline Tacaimbó & 0.554 & 0.088 & 0.441 \\
\hline Tacaratu & 0.573 & -0.098 & 0.331 \\
\hline Tamandaré & 0.593 & 0.005 & 0.437 \\
\hline Taquaritinga do Norte & 0.641 & 0.494 & 0.125 \\
\hline Terezinha & 0.545 & 0.292 & 0.294 \\
\hline Terra Nova & 0.599 & 0.048 & 0.142 \\
\hline Timbaúba & 0.618 & 0.155 & 0.245 \\
\hline Toritama & 0.618 & 0.423 & 0.076 \\
\hline Tracunhaém & 0.605 & 0.229 & 0.004 \\
\hline Trindade & 0.595 & 0.002 & 0.208 \\
\hline Triunfo & 0.670 & -0.565 & 0.286 \\
\hline Tupanatinga & 0.519 & 1.656 & 0.013 \\
\hline Tuparetama & 0.634 & 0.348 & 0.218 \\
\hline Venturosa & 0.592 & 0.040 & 0.087 \\
\hline Verdejante & 0.605 & 0.134 & 0.148 \\
\hline Vertente do Lério & 0.563 & 0.186 & 0.333 \\
\hline Vertentes & 0.582 & -0.108 & 0.197 \\
\hline Vicência & 0.605 & 0.064 & 0.200 \\
\hline Vitória de Santo Antão & 0.640 & 0.673 & 0.032 \\
\hline Xexéu & 0.552 & 0.330 & 0.225 \\
\hline
\end{tabular}

Source: Authors' elaboration based on the Human Development Atlas in Brazil7.

Regarding social distance, children felt strong direct and indirect effects on their physical and psychological health ${ }^{12}$. The availability of diagnostic tests was also limited for children, since they were offered to more unwell patients, thereby leading to a probable pediatric underreporting ${ }^{13}$.
These factors added together revealed the lack of effective social protection policies and limitations to guarantee families' access to emergency aid from the federal government. The lack of incentives in the face of the pandemic is reflected in the insufficient primary health care actions and the lack of social protection. 
The new severe COVID_19 cases in Pernambuco showed similar characteristics in the clusters, which indicated a direct association between the cases studied and the Municipal Human Development Index. Although this association is only weak because of the locoregional heterogeneity. Social inequality is evident in the territorial areas of this state, which implies the diversity of factors inherent to specific social dynamics.

From the data of this study, it can be seen that at the beginning of the pandemic, severe COVID-19 cases in children were more concentrated in the municipal urban centers. Over the months, dissemination progressed rapidly to the countryside. Brazil is a country with vast territorial extensions, and the economic, social, and cultural inequalities are among the greatest challenges in ensuring equitable actions in health and healthcare.

During the COVID-19 pandemic, there was an increase in severe cases of COVID-19 in the population under 10 years of age. The available figures may be associated with possible underreporting. This finding serves as a public health warning. Although children are less susceptible to severe forms of COVID-19, the involvement of this age group may be indicative of a family contagion and the possibility of prolonged dissemination by the child/children, even after recovery from their symptomatic condition ${ }^{13}$.

In addition to family contacts, another contagion factor is the history of exposure to epidemic areas or both. In a study conducted with 171 children infected by SARS-CoV-2 admitted to the Children's Hospital in Wuhan, 90.1\% had contact with infected family members or with suspected COVID-19 cases $^{14}$.

Children are susceptible to SARS-CoV-2 and can display asymptomatic or mild forms of COVID-19. Transmissibility in children has contributed substantially to the chain of community transmission, with considerable viral dissemination ${ }^{15}$. From this perspective, attention should not be focused only on the disease, but on the severity of dissemination and daily life in which the health-disease process is evidenced by spatially determining the social relations that must be considered in public health policies.

The underreporting of COVID-19 cases in children due to the scarcity of tests, testing only symptomatic individuals, and the use of secondary data subject to constant variations, were the limitations of this study. However, these data have been widely used as a consistent tool to support management and epidemiological investigations.

Finally, the distribution of pediatric COVID-19 did not occur homogeneously among the municipalities in Pernambuco. The high rates correlated with the areas where children live. The progression of severe infection among children in the less developed municipalities should serve as a warning to health policy makers to "geo-target" human/financial resources and control and surveillance measures for vulnerable communities. In addition, the municipalities with an absence of severe COVID-19 in children or those with Low-Low patterns still need combined measures to prevent the disease from spreading to these locations and thus, should be monitored.

\section{AUTHORS' CONTRIBUTION}

APSCS and ERH contributed substantially to the design of the manuscript, analysis and interpretation of data, critical review of the content. PDA and MVAF contributed significantly to the interpretation of data and critical review of the content; all authors approved the final version of the manuscript.

\section{CONFLICT OF INTEREST}

The authors declare that there is no conflict of interest.

\section{ORCID}

Amanda Priscila de Santana Cabral Silva: 0000-0003-2337-9925

Eliane Rolim de Holanda: 0000-0001-6433-9271

Paula Daniella de Abreu: 0000-0001-8756-8173

Marcelo Victor de Arruda Freitas: 0000-0003-2709-7423

\section{REFERENCES}

1. Clecland J, Tan ECP, Than KY, Low-Beer N. How Covid-19 opened up questions of sociomateriality in healthcare education. Adv in Health Sci Educ. 2020;25(2):479-82.

2. Oviedo N, Carvalho G. COVID-19 em pediatria: O muito que ainda não se sabe! Gaz Med Port. 2020;7(2):192-8.

3. Silva JRA, Argentino ACA, Dulaba LD, Bernardelli RR, Campiolo EL. COVID-19 em Pediatria: um panorama entre incidência e mortalidade. Rev Residência Pediátrica. Sociedade Brasileira de Pediatria. 2020;(383).

4. Minayo MCS, Freire NP. Pandemia exacerba desigualdades na Saúde. Ciênc Saúde Coletiva. 2020;25(9):3555-6.

5. Ministério do Planejamento, Orçamento e Gestão (MPOG). Instituto Brasileiro de Geografia e Estatística (IBGE). Pernambuco. Panorama [Internet]. Brasília: MPOG; 2020. [cited 2020 Set 21] Available from: https://cidades.ibge.gov.br/brasil/pe/panorama.

6. Silva APSC, Maia LTS, Souza WV. Síndrome Respiratória Aguda Grave em Pernambuco: Comparativo dos padrões antes e durante a pandemia de COVID-19. Cien Saude Colet [Internet]. 2020. [updated 2020 Ago; cited 2020 Set 18]. Available from: http://www. cienciaesaudecoletiva.com.br/artigos/sindrome-respiratoria-agudagrave-em-pernambuco-comparativo-dos-padroes-antes-e-durante-apandemia-de-covid19/17720?id $=17720$.

7. Ministério da Saúde (MS). Atlas de Desenvolvimento Humano no Brasil [Internet]. Brasília: MS;2013. [cited 2020 Set 21] Available from: http:// atlasbrasil.org.br/consulta/.

8. Carneiro FF, Franco Netto G, Corvalan C, de Freitas CM, Sales LBF. Saúde ambiental e desigualdades: Construindo indicadores para o desenvolvimento sustentável. Ciênc Saúde Coletiva. 2012;17(6):1419-25.

9. Maciel JAC, Castro-Silva II, Farias MR. Análise inicial da correlação espacial entre a incidência de COVID-19 e o desenvolvimento humano nos municípios do estado do Ceará no Brasil. Rev Bras Epidemiol. 2020;23:e200057.

10. Ministério do Planejamento, Orçamento e Gestão (MPOG). Instituto Brasileiro de Geografia e Estatística (IBGE). Cartas e mapas [Internet]. Brasília: MPOG; 2014. [cited 2020 Set 21] Available from: http://www. ibge.gov.br.

11. Secretaria de Planejamento e Gestão (SEPLAG). Secretaria de Saúde (SES). Agência Estadual de Tecnologia da Informação (ATI). Covid-19 em Dados [Internet]. Pernambuco: SEPLAG/SES/ATI;2020. [cited 2020 
Set 21] Available from: https://dados.seplag.pe.gov.br/apps/corona dados.html.

12. Chanchlani N, Buchanan F, Gill PJ. Addressing the indirect effects of COVID-19 on the health of children and young people. CMAJ. 2020;192(32): E921-E927.

13. Mao L, Xu J, Xu Z, Xia X, Li B, He J, et al. A child with household transmitted COVID19. BMC Infect Dis. 2020;20:329.
14. LU X, Zhang L, Du H, Zhang J, Li YY, Qu J, et al. SARS-CoV-2 Infection in Children. N Engl J Med. 2020;382(17):1663-5.

15. Safadi MA. The intriguing features of COVID-19 in children and its impact on the pandemic. J Pediatr (Rio J). 2020;96:265-8. 